\title{
Radiation, work experience, and cause specific mortality among workers at an energy research laboratory
}

\author{
H CHECKOWAY, ${ }^{1} \mathrm{R}$ M MATHEW,' C M SHY, $\mathrm{J}$ E WATSON, JR, ${ }^{2}$ W G TANKERSLEY, ${ }^{3}$ \\ SUSANNE H WOLF,' JOANNA C SMITH,' AND SHIRLEY A FRY ${ }^{3}$
}

From the Departments of Epidemiology ${ }^{1}$ and Environmental Sciences and Engineering, ${ }^{2}$ University of North Carolina, Chapel Hill, NC 27514, and the Oak Ridge Associated Universities, Center for Epidemiologic Research, ${ }^{3}$ Oak Ridge, TN, USA

ABSTRACT A retrospective cohort mortality study was conducted among 8375 white male employees who had worked at the Oak Ridge National Laboratory for at least one month between 1943 and 1972. This plant has been the site of energy related research, including uranium and plutonium reactor technology and radioisotope production. Radiation doses, primarily from gamma rays, were generally low; the median cumulative exposure for workers was 0.16 rems. Historical follow up was conducted for the years 1943-77 and ascertainment of vital status was achieved for $92.3 \%$ of the cohort. Standardised mortality ratios (SMRs) were computed to contrast the subjects' cause specific mortality experience with that of the United States white male population. The observed number of 966 deaths from all causes was $73 \%$ of the number expected. Mortality deficits were also seen for arteriosclerotic heart disease (SMR $=0.75 ; 344$ observed) and all cancers (SMR $=0.78 ; 194$ observed). These results are indicative of the healthy worker effect and the favourable influence on health of the cohort's relatively high socioeconomic status. Non-statistically significant raised SMRs were seen for all leukaemias $(\mathrm{SMR}=1 \cdot 49,16$ observed), cancer of the prostate (SMR $=1 \cdot 16,14$ observed), and Hodgkin's disease $(\mathrm{SMR}=1 \cdot 10,5$ observed). Internal comparisons of mortality (standardised rate ratios, SRRs) were made between subgroups of the cohort according to radiation dose level and duration of employment in various job categories. No consistent gradients of cause specific mortality were detected for radiation exposure. Leukaemia mortality was highest among workers with $\geqslant 10$ years employment in engineering $(S R R=2 \cdot 40)$ and maintenance $(S R R=3 \cdot 12)$ jobs. The association of leukaemia with employment in engineering was unexpected; maintenance jobs entail potential exposures to radiation and to a wide range of organic chemicals, metals, and other substances.

Excess risks of cancer have been established as sequelae of occupational exposures to doses of ionising radiation in excess of 100 rads from studies of uranium miners,' other underground metals miners, ${ }^{23}$ radium dial painters, ${ }^{4}$ and radiologists. ${ }^{5}$ The evidence relating a rise in the mortality rate from cancer to low level ( $<50$ rads) occupational exposure to radiation is controversial. A fivefold propor-

Received 10 September 1984 Accepted 15 November 1984 tionate mortality excess for leukaemia was reported in a study of nuclear shipyard workers in New England ${ }^{6}$ but was not confirmed on subsequent enumeration and identification of the complete cohort.' In 1977 Mancuso et al reported significant excesses of myeloid leukaemia, multiple myeloma, and pancreatic and lung cancers among workers at the Hanford nuclear plant, where cumulative doses were generally less than 10 rems. $^{8}$ This study has been the object of considerable criticism, ${ }^{10}$ however, and subsequent analyses of the data have confirmed only the radiation related association with multiple 
myeloma among people with cumulative doses greater than 15 rems. ${ }^{11-15}$.

The present investigation is a retrospective cohort mortality study of workers exposed to low doses of ionising radiation at a national energy research laboratory. The objective was to examine mortality patterns in relation to occupational radiation doses and with respect to job assignment experience at the plant.

\section{Methods and materials}

\section{STUDY SETTING}

The Oak Ridge National Laboratory (ORNL) located in Oak Ridge, Tennessee, was founded in 1943 as part of the second world war Manhattan Project. Its original functions were to provide facilities for research and development for the atomic pile project, to serve as a pilot plant for the Hanford Engineer Works, and to produce small quantities of plutonium. In postwar years ORNL has expanded its scope of activities to include fission and fusion power research, heavy element ion research, chemical processing and separation of radioisotopes, and basic research in the engineering, physical, and biological sciences.

\section{STUDY POPULATION}

During 1943-77, 20646 people worked at ORNL. The population of ORNL workers was first enumerated from personnel files in 1964 by Mancuso and his co-workers from the University of Pittsburgh, and the enumeration has been updated subsequently from the same files. The study cohort was restricted to 8375 white men who worked for periods of at least 30 days at any time from 1 January 1943 to 31 December 1972. The duration of employment was determined from job history records. The cohort was restricted to those not known to have worked at any other plant of the United States Department of Energy or its predecessor organisations. This restriction was imposed in an attempt to limit the evaluation of occupational exposures and related health effects to those pertinent to ORNL. Hourly and salary paid workers were included in the study population. Table 1 summarises the numbers of workers and their reasons for exclusion or inclusion in the final study cohort. Table 2 shows the age at hire and table 3 the duration of service of the cohort.

\section{FOLLOW UP}

Historical follow up of the cohort up to 31 December 1977 was achieved by means of repeated submissions of the cohort roster to the Social Security Administration. Ancillary sources of vital status information were the Tennessee Motor Vehi-
Table 1 Study cohort definition with inclusion and exclusion criteria

\begin{tabular}{lc}
\hline Total No of workers 1943-77 & 20646 \\
Exclusions: & 3341 \\
Women or unknown sex & 1353 \\
Black or unknown race & 5361 \\
Employment in other plants* & 1639 \\
First hired after 1 January 1973 & 365 \\
Erroneous or unknown employment dates & 3 \\
Unknown birth date & 209 \\
Employed less than 30 days & 8375 \\
Final study cohort $\dagger$ & \\
\hline *Other United States Department of Energy, or predecessor \\
organisation, facilities. \\
tWhite men employed for 30 or more days during 1 January 1943 \\
to 31 December 1972.
\end{tabular}

Table 2 Age at hire distribution for 8375 white male workers

\begin{tabular}{lcc}
\hline Age $^{*}$ & No & Percentage \\
\hline$<20$ & 639 & $7 \cdot 6$ \\
$20-29$ & 4376 & $52 \cdot 3$ \\
$30-39$ & 2322 & $27 \cdot 7$ \\
$40-49$ & 802 & $9 \cdot 6$ \\
$50-59$ & 208 & $2 \cdot 5$ \\
$\geqslant 50$ & 28 & $0 \cdot 3$ \\
\hline
\end{tabular}

${ }^{*}$ Mean $=29 \cdot 3$, median $=28 \cdot 0$, range $=16-67$.

Table 3 Duration of employment distribution for 8375 white male workers

\begin{tabular}{lll}
\hline $\begin{array}{l}\text { Duration of } \\
\text { employment (years) }\end{array}$ & No & Percentage \\
\hline$<1$ & 2895 & $34 \cdot 6$ \\
$1-4$ & 2014 & $24 \cdot 0$ \\
$5-9$ & 806 & $9 \cdot 6$ \\
$10-19$ & 1248 & $14 \cdot 9$ \\
$20-29$ & 1112 & $13 \cdot 3$ \\
$\geqslant 30$ & 300 & $3 \cdot 6$ \\
\hline
\end{tabular}

${ }^{*}$ Mean $=8 \cdot 0$, median $=2 \cdot 6$, range $=<1-34 \cdot 4$.

cles Department and death indexes for Tennessee and surrounding states. Death certificates, obtained from state bureaux of vital statistics, were coded according to the eighth revision of the International Classification of Diseases (ICDA).

Vital status was determined for $92.2 \%$ of the cohort. A total of 966 deaths was identified and death certificates were obtained for $939(97.2 \%)$ of these deaths (table 4). The 648 workers with unknown vital status were considered to be alive and contributed person-years of observation up to the date of termination of employment. Workers with less than six months' service and foreign consultants accounted for most of the people with unknown vital status. As shown in table 5, more than $75 \%$ of the cohort was followed up for at least 10 years, and the median duration of follow up was 20 years. The cohort contributed a total of 164004 person-years 
Table 4 Vital status of 8375 white male workers on 31 December 1977

\begin{tabular}{lcc}
\hline Vital status & No & Percentage \\
\hline Alive & 6761 & 80.7 \\
Dead & 966 & $11 \cdot 5$ \\
With death certificates & $(939)$ & $(97 \cdot 2)$ \\
Without death certificates & $(27)$ & $(2 \cdot 8)$ \\
Unknown & 648 & 7.7 \\
Total & 8375 & \\
\hline
\end{tabular}

Table 5 Duration of follow up distribution for 8375 white male workers

\begin{tabular}{lcc}
\hline $\begin{array}{l}\text { Duration of } \\
\text { follow up (years) }\end{array}$ & No & Percentage \\
\hline$<1$ & 316 & $3 \cdot 8$ \\
$1-4$ & 319 & $3 \cdot 8$ \\
$5-9$ & 664 & $7 \cdot 9$ \\
$10-19$ & 2795 & $33 \cdot 4$ \\
$20-29$ & 2729 & $32 \cdot 6$ \\
$\geqslant 30$ & 1552 & $18 \cdot 5$ \\
\hline
\end{tabular}

${ }^{*}$ Mean $=19 \cdot 2$, median $=20 \cdot 0$, range $=<1-34 \cdot 0$.

of observation, which represents $93 \%$ of the theoretical total person-years $(175870)$ that could have resulted had all untraced cohort members lived until the end of the study period.

\section{RADIATION EXPOSURE}

Information on exposure to radiation was obtained from ORNL computer tapes containing personnel monitoring data for external and internal sources of radiation. Monitoring for penetrating external radiation, primarily gamma rays, began in 1943. Film badges were used for most of the time considered; thermoluminescent dosimeters have been in use since 1975. Pocket chambers were used as the primary dosimeters only in 1943 and 1944. Until the early 1950 s external radiation monitoring was required only for workers entering designated areas where the potential for exposure was presumed to exist; film badge monitoring has been routine for all workers since 1951 . From 1944 to 1956 film badges were evaluated weekly; thereafter, the monitoring periods were quarterly. In the present analysis the annual cumulative dose, expressed in rems, has been used as the unit of exposure.

Table 6 presents the distribution of cumulative external radiation doses received by cohort members. The 597 workers with unknown dose include those who worked before radiation monitoring was performed routinely throughout the plant. The cumulative doses were generally low, the median dose was only 0.16 rems, and only a small fraction of the cohort $(7.2 \%)$ accumulated doses in excess of 5 rems. The total population dose for those with known values was 13471.5 rems.
Table 6 Cumulative external radiation dose (rems) distribution for 8375 white male workers

\begin{tabular}{lll}
\hline Dose (rems) & No & Percentage \\
\hline 0 & 2162 & 25.8 \\
$0.001-0.099$ & 1318 & 15.7 \\
$0 \cdot 100-0.499$ & 1345 & 16.1 \\
$0 \cdot 500-0.999$ & 779 & $9 \cdot 3$ \\
$1.000-1.999$ & 845 & 10.1 \\
$2 \cdot 000-4.999$ & 724 & $8 \cdot 6$ \\
$5 \cdot 000-9.999$ & 308 & 3.7 \\
$\geqslant 10$ & 297 & 3.5 \\
Unknown & 597 & 7.1 \\
\hline
\end{tabular}

${ }^{*}$ Mean $=1 \cdot 732$, median $=0 \cdot 160$, range $=0-107 \cdot 835$.

Radioisotopes handled during production and research activities were the principal source of internal contamination. Evidence of the extent of such contamination was determined by urine and faecal bioassays and by whole body counting (in vivo gamma spectroscopy). The bioassay programme, begun in 1951, and whole body counting, begun in 1962 , continue to the present. Throughout, only persons considered potentially at risk for internal contamination were monitored. The doses of radiation contributed by internally deposited radionuclides were not available because the data needed to compute doses for the many different radionuclides used at ORNL were not computerised, and the effort that would be required to do so was not considered to be justified for this analysis. Knowledgeable plant health physicists and monitoring personnel report that internal radiation doses have been substantially lower than external doses. Also, because a high degree of correlation probably exists between levels of the two types of exposures, separate analyses of mortality patterns in relation to internal doses would probably be redundant.

\section{JOB CATEGORIES}

The workers' employment records contain detailed information on jobs and departments and the associated dates of employment. Several hundred distinct job and department classifications were grouped into 11 broad job categories considered to be relatively similar with respect to job duties and potential for exposure to radiological and nonradiological substances. The assignments were based on reviews of job descriptions, materials used and, where data permitted, on health physics and industrial hygiene monitoring data. Knowledgeable plant personnel assisted in this effort; the job categories are described in table 7.

STATISTICAL ANALYSIS

The overall mortality patterns of the cohort were examined by means of contrasts with the experience 
Table 7 Job categories and person-years of work

\begin{tabular}{|c|c|c|c|}
\hline \multirow[t]{2}{*}{ Job category } & \multirow[t]{2}{*}{ Description } & \multicolumn{2}{|c|}{ Person-years of work } \\
\hline & & $\overline{N o}$ & $\%$ of total \\
\hline $\begin{array}{l}1 \text { Radioisotopes and } \\
\text { radiation producing } \\
\text { machinery }\end{array}$ & $\begin{array}{l}\text { Production and handling of radioisotopes and } \\
\text { operation and maintenance of radiation } \\
\text { producing devices }\end{array}$ & 1805 & $2 \cdot 8$ \\
\hline 2 Chemical operations & $\begin{array}{l}\text { Production and handling of chemicals on pilot } \\
\text { plant or industrial scale: does not include } \\
\text { chemists or laboratory workers }\end{array}$ & 466 & 0.7 \\
\hline $\begin{array}{l}3 \text { Monitoring } \\
4 \text { Biology } \\
5 \text { Chemistry } \\
6 \text { Physics } \\
7 \text { Engineering }\end{array}$ & $\begin{array}{l}\text { Health physics, industrial hygiene, plant safety } \\
\text { Senior scientists and research technicians } \\
\text { Senior scientists and research technicians } \\
\text { Senior scientists and research technicians } \\
\text { Engineers involved in design, development, } \\
\text { construction, and hazards control activities }\end{array}$ & $\begin{array}{r}2148 \\
2656 \\
9165 \\
4660 \\
13952\end{array}$ & $\begin{array}{r}3 \cdot 3 \\
4 \cdot 1 \\
14 \cdot 1 \\
7 \cdot 1 \\
21 \cdot 4\end{array}$ \\
\hline $\begin{array}{l}8 \text { Administration } \\
9 \text { Maintenance }\end{array}$ & $\begin{array}{l}\text { Executives, management, and support office personnel } \\
\text { Mechanical and electrical workers responsible for } \\
\text { routine and repair service for laboratory, pilot } \\
\text { plant, and operations equipment }\end{array}$ & $\begin{array}{r}4641 \\
14915\end{array}$ & $\begin{array}{r}7 \cdot 1 \\
22 \cdot 9\end{array}$ \\
\hline 10 Shipping and receiving & $\begin{array}{l}\text { Warehousing, storage, and distribution of } \\
\text { packaged materials }\end{array}$ & 920 & 1.4 \\
\hline 11 Other & $\begin{array}{l}\text { Security, laundry, janitors, load service, } \\
\text { auto maintenance }\end{array}$ & 5367 & $8 \cdot 2$ \\
\hline 12 Unknown & Insufficient or unavailable job history information & 4521 & 6.9 \\
\hline Total & & 65216 & 100 \\
\hline
\end{tabular}

of the United States (1943-77) and Tennessee (1950-77) white male populations. A modified life table analysis program developed by Monson ${ }^{16}$ was used to compare cause specific observed numbers of deaths with expected numbers, adjusted for age and calendar year. Summary results were expressed as ratios of observed to expected numbers of deaths (standardised mortality ratios (SMRs)). Statistical significance testing for SMRs was performed by comparing observed with expected numbers of deaths, assuming a Poisson distribution of the observed numbers. ${ }^{17}$

In the evaluation of cause specific mortality in relation to external radiation exposure, personyears of observation, by five year age and calendar year groups, were allocated to the following cumulative dose categories: $0,0 \cdot 001-0.999,1 \cdot 000-4 \cdot 999$, and $>5$ rems. The allocation of person-years was done such that a worker contributed person-years in every achieved exposure category. Standardised rate ratios (SRRs) were computed for each dose group, using the joint age and calendar year person-years distribution of the 0 rem category as the standard. SRRs are analogous to directly adjusted rate ratios, and as such may be validly compared. ${ }^{18}$ The 597 workers for whom radiation dose data were missing were excluded from this set of analyses.

Latency analyses were also performed in which neither person-years nor observed deaths were included for the first five, 10, or 15 years of the workers' employment experience. Additionally, in the latency analyses dose levels were lagged by varying durations $(5,10$, or 15 years) such that a worker's person-time of observation for a given age and calendar year were allocated to the dose category achieved five, 10 , or 15 years previously, depending on the latent interval assumed. A similar approach has been used previously by Gilbert and Marks in their analysis of mortality at the Hanford facility. Thus, for example, if a 10 year latency is assume for a worker who had accrued cumulative externa radiation doses of 3 rems by age 40 in 1950 and $\bar{Q}$ rems by age 50 in 1960, his person-year of observation for age 50 and calendar year 1960 would be allocated to the 1.000-4.999 rems dose category, and accordingly, his person-years for ages 51-59 would be allocated to the dose categories achieved at ages 41-49 during the years 1951-9.

SRRs were computed for selected causes of death for three duration of employment categories, $<1$ (including 0 ), 1-9, and $\geqslant 10$ years, for each of the 12 (including unknown) job categories. Age and calendar-year stratified person-years were allocated to all employment duration categories achieved. Counting of person-years for the $<1,1-9$, and $\geqslant 10$ categories began 30 days after first employment, at the exact date and age when one year of employ- $\rightarrow$ ment in a job category was reached, and at the exact date and age when 10 years of employment in that $N$ job category was attained, respectively.

\section{Results}

OVERALL FINDINGS

Table 8 shows the cause-specific SMRs, relative to the United States white male population for the $\stackrel{\mathcal{P}}{?}$ years 1943-77. The SMR of 0.73 (966 observed $v$ 
Radiation, work experience, and cause specific mortality among workers at an energy research laboratory 529

Table 8 Cause specific SMRs for white male workers compared with United States white men, 1943-77

\begin{tabular}{|c|c|c|c|}
\hline Cause of death (8th rev ICD) & Observed deaths & Expected deaths & $S M R$ \\
\hline $\begin{array}{l}\text { All causes } \\
\text { All cancers (140-209) } \\
\text { Cancer of oesophagus (150) } \\
\text { Cancer of stomach }(151) \\
\text { Cancer of large intestine (153) } \\
\text { Cancer of rectum }(154) \\
\text { Cancer of pancreas }(157) \\
\text { Cancer of lung }(162-163) \\
\text { Cancer of prostate }(185) \\
\text { Cancer of brain and central nervous system (191-192) } \\
\text { Lymphosarcoma and reticulosarcoma (200) } \\
\text { Hodgkin's disease (201) } \\
\text { Other lymphatic cancer (202-203) } \\
\text { Leukaemia and aleukaemia (204-207) } \\
\text { Arteriosclerotic heart disease }(410-413) \\
\text { Cerebrovascular disease (430-438) } \\
\text { Diabetes mellitus }(250) \\
\text { Non-malignant respiratory diseases (460-519) } \\
\text { Digestive system diseases (520-577) } \\
\text { Genitourinary system diseases }(580-629) \\
\text { Diseases of blood forming organs (280-289) } \\
\text { Motor vehicle accidents (E810-E827) } \\
\text { Suicide (E950-E959) }\end{array}$ & $\begin{array}{r}966 \\
194 \\
4 \\
12 \\
12 \\
2 \\
11 \\
59 \\
14 \\
9 \\
5 \\
5 \\
2 \\
16 \\
344 \\
62 \\
10 \\
42 \\
26 \\
15 \\
2 \\
36 \\
39\end{array}$ & $\begin{array}{r}1319 \cdot 99 \\
249.98 \\
5.78 \\
13.36 \\
21 \cdot 29 \\
8 \cdot 01 \\
13 \cdot 59 \\
79 \cdot 10 \\
12.04 \\
9.40 \\
6 \cdot 26 \\
4.53 \\
5.62 \\
10.77 \\
459 \cdot 89 \\
76.92 \\
18 \cdot 34 \\
69 \cdot 19 \\
72.03 \\
18.22 \\
3.08 \\
60.15 \\
40.15\end{array}$ & $\begin{array}{l}0.73^{* *} \\
0.78^{* *} \\
0.69 \\
0.90 \\
0.56 \\
0.25 \\
0.81 \\
0.75^{*} \\
1.16 \\
0.96 \\
0.80 \\
1.10 \\
0.36 \\
1.48 \\
0.75^{* *} \\
0.81 \\
0.55 \\
0.61 \\
0.36^{* *} \\
0.82 \\
0.65 \\
0.60^{* *} \\
0.97\end{array}$ \\
\hline
\end{tabular}

${ }^{*} \mathrm{p}<0.05 ;{ }^{* *} \mathrm{p}<0.01$.

1319.99 expected) for all causes of death was significantly low $(p<0.01)$. Mortality deficits from arteriosclerotic heart disease (344 observed $v$ 499.89 expected) and from all cancer sites combined (194 observed $v 249.98$ expected) were the principal contributors to the deficit in overall mortality. Mortality was less than expected for most site specific cancers, including a statistically significant deficit of lung cancer (SMR = 0.75, 59 observed); the exceptions were leukaemia (SMR $=1.48,16$ observed), cancer of the prostate (SMR $=1 \cdot 16,14$ observed), and Hodgkin's disease (SMR $=1 \cdot 10,5$ observed).

The only available mortality data for Tennessee white men were five year age and calendar year specific cancer mortality rates for the years 1950 77; consequently, mortality comparisons with the state population were restricted to cancer causes of death for those years (table 9). The SMRs relative to the Tennessee mortality experience are generally in close agreement with the results from table 8 . The notable exceptions are the increased SMRs for stomach cancer (SMR $=1 \cdot 22,12$ observed) and Hodgkin's disease (SMR $=1 \cdot 36,5$ observed).

Only one death was attributable to multiple myeloma, a disease that has been identified in excess in some irradiated populations. ${ }^{19}$ The expected number, based on Tennessee rates, is 3.38. (Multiple myeloma is included with "other lymphoid cancers" in the United States population rates.)

\section{RADIATION EXPOSURE}

SRRs were calculated for four categories of cause of death; all causes, all cancers (ICD 140-209), leukaemia (ICD 204-207), and cancer of the prostate (ICD 185). Interest here was in examining dose effect trends for mortality from all causes and all cancers and for the two cancers for which overall

Table 9 Site specific cancer SMRs for white male workers compared with Tennessee white men, 1950-77

\begin{tabular}{|c|c|c|c|}
\hline Cause of death (8th rev ICD) & Observed deaths & Expected deaths & $S M R$ \\
\hline $\begin{array}{l}\text { All cancers }(140-207) \\
\text { Cancer of oesophagus }(150) \\
\text { Cancer of stomach }(151) \\
\text { Cancer of large intestine (153) } \\
\text { Cancer of rectum }(154) \\
\text { Cancer of pancreas }(157) \\
\text { Cancer of lung }(162-163) \\
\text { Cancer of prostate }(185) \\
\text { Cancer of brain and central nervous system (191-192) } \\
\text { Lymphosarcoma and reticulosarcoma and other } \\
\text { lymphoma }(200,202)\end{array}$ & $\begin{array}{r}190 \\
4 \\
12 \\
12 \\
2 \\
11 \\
58 \\
14 \\
8 \\
6\end{array}$ & $\begin{array}{r}240.02 \\
4 \cdot 43 \\
9.88 \\
15 \cdot 90 \\
4 \cdot 78 \\
13 \cdot 57 \\
87 \cdot 22 \\
11.87 \\
11.48 \\
7 \cdot 89\end{array}$ & $\begin{array}{l}0.79^{* *} \\
0.90 \\
1.22 \\
0.75 \\
0.42 \\
0.81 \\
0.66^{* *} \\
1 \cdot 18 \\
0.70 \\
0.76\end{array}$ \\
\hline $\begin{array}{l}\text { Hodgkin's disease (201) } \\
\text { Multiple myeloma (203) } \\
\text { Leukaemia and aleukaemia (204-207) }\end{array}$ & $\begin{array}{r}5 \\
1 \\
16\end{array}$ & $\begin{array}{r}3 \cdot 67 \\
3 \cdot 38 \\
10 \cdot 72\end{array}$ & $\begin{array}{l}1 \cdot 36 \\
0 \cdot 30 \\
1 \cdot 49\end{array}$ \\
\hline
\end{tabular}

$*$ * $p<0.01$. 
excesses were noted, based on more than five observed deaths. The results with 0 and 10 year latency assumptions are contained in table 10 . There was no evidence of mortality gradients for all causes, all cancers, or for cancer of the prostate. The leukaemia SRRs increased up to the 1.000-4.999 rems dose category $(S R R=3.76)$, but no deaths from leukaemia were found among persons with $\geqslant 5$ rems. One death from leukaemia (case 8 , see table 14) was not included in the analysis because there was no information on radiation dose. The patterns of mortality for the 0 and 10 year latency analyses were similar within each of the four cause of death categories considered.

Analyses were also performed for leukaemia mortality in which SRRs were computed assuming latency periods of five and 15 years; the findings are summarised in table 11 . Varying the latency interval caused some fluctuations in the SRRs, but the pattern of a peak at the $1.000-4.999$ rems category, that fell to zero at the $\geqslant 5$ rems category, occurred uniformly.

\section{ANALYSIS BY JOB CATEGORY}

SRRs for all cancer sites combined were computed according to duration of employment for each of the job categories (table 12). There is no regular pattern of increasing cancer mortality for any job category.

Table 13 gives similar analyses performed for leukaemia mortality. Among the job categories considered, only maintenance and engineering exhibited positive gradients, although the SRRs for the 1-9 and $\geqslant 10$ year categories were based on small numbers. The most striking finding is the increasing pattern of SRRs for maintenance, for which the SRRs were 1.91 ( 4 observed) and $3 \cdot 12$ ( 3 observed) for the $1-9$ and $\geqslant 10$ year duration categories, respectively. The findings from five, 10 , and 15 year latency analyses (not shown) were not materially different from these results.

No consistent associations emerged from the results of SRR analyses for cancer of the prostate according to employment duration in these job categories. These findings are not presented.

\section{Discussion}

The most notable general findings from this study are the low mortality rates for most causes of death among ORNL workers when compared with the United States population. Deficits in mortality from all causes and for some specific causes, such as cardiovascular diseases, are commonly attributed to the healthy worker effect. ${ }^{20}$ This phenomenon is usually

Table 10 SRRs for selected causes of death according to radiation dose category for 0 and 10 year latency intervals

\begin{tabular}{|c|c|c|c|c|c|c|c|c|}
\hline \multirow{3}{*}{$\begin{array}{l}\text { Cause of death/ } \\
\text { latency (years) }\end{array}$} & \multicolumn{8}{|c|}{ Dose category (rems) } \\
\hline & \multicolumn{2}{|l|}{$\overline{0^{*}}$} & \multicolumn{2}{|c|}{$0.001-0.999$} & \multicolumn{2}{|c|}{$1.000-4.999$} & \multicolumn{2}{|l|}{$\geqslant 5$} \\
\hline & $(O b s)$ & $S R R$ & $(O b s)$ & $S R R$ & $(\mathrm{Obs})$ & $S R R$ & (Obs) & $S R R$ \\
\hline $\begin{array}{c}\text { All causes: } \\
0 \\
10 \\
\text { All cancers: }\end{array}$ & $\begin{array}{l}(221) \\
(193)\end{array}$ & $\begin{array}{l}1 \cdot 00 \\
1 \cdot 00\end{array}$ & $\begin{array}{l}(380) \\
(351)\end{array}$ & $\begin{array}{l}0.89 \\
0.94\end{array}$ & $\begin{array}{l}(243) \\
(164)\end{array}$ & $\begin{array}{l}1 \cdot 00 \\
0.84\end{array}$ & $\begin{array}{l}(60) \\
(46)\end{array}$ & $\begin{array}{l}0.68 \\
0.70\end{array}$ \\
\hline $\begin{array}{c}0 \\
10 \\
\text { Leukaemia: }\end{array}$ & $\begin{array}{l}(37) \\
(34)\end{array}$ & $\begin{array}{l}1 \cdot 00 \\
1 \cdot 00\end{array}$ & $\begin{array}{l}(78) \\
(73)\end{array}$ & $\begin{array}{l}1.07 \\
1.06\end{array}$ & $\begin{array}{l}(55) \\
(36)\end{array}$ & $\begin{array}{l}1 \cdot 28 \\
0.97\end{array}$ & $\begin{array}{l}(13) \\
11)\end{array}$ & $\begin{array}{l}0.84 \\
0.90\end{array}$ \\
\hline $\begin{array}{l}0 \\
10 \\
\text { Prostate cancer: }\end{array}$ & $\begin{array}{l}(2) \\
(2)\end{array}$ & $\begin{array}{l}1 \cdot 00 \\
1 \cdot 00\end{array}$ & $\begin{array}{l}(4) \\
(6)\end{array}$ & $\begin{array}{l}0 \cdot 96 \\
1 \cdot 38\end{array}$ & $\begin{array}{l}(9) \\
(6)\end{array}$ & $\begin{array}{l}3 \cdot 76 \\
2 \cdot 70\end{array}$ & $\begin{array}{l}(0) \\
(0)\end{array}$ & $\begin{array}{l}0 \\
0\end{array}$ \\
\hline $\begin{array}{r}0 \\
10\end{array}$ & $\begin{array}{l}(4) \\
(4)\end{array}$ & $\begin{array}{l}1 \cdot 00 \\
1 \cdot 00\end{array}$ & (5) & $\begin{array}{l}0.57 \\
0.65\end{array}$ & (5) & $\begin{array}{l}1.04 \\
0.94\end{array}$ & (0) & $\begin{array}{l}0 \\
0\end{array}$ \\
\hline
\end{tabular}

*Reference category.

Table 11 SRRs for leukaemia mortality, by radiation dose category, under varying estimates of latency

\begin{tabular}{|c|c|c|c|c|c|c|c|c|}
\hline \multirow{3}{*}{$\begin{array}{l}\text { Latency interval } \\
\text { (years) }\end{array}$} & \multicolumn{8}{|c|}{ Dose category (rems) } \\
\hline & \multicolumn{2}{|l|}{$0^{*}$} & \multicolumn{2}{|c|}{$0.001-0.999$} & \multicolumn{2}{|c|}{$1.000-4.999$} & \multicolumn{2}{|l|}{$\geqslant 5$} \\
\hline & (Obs) & $S R R$ & (Obs) & $S R R$ & (Obs) & $S R R$ & (Obs) & $S R R$ \\
\hline $\begin{array}{r}0 \\
5 \\
10 \\
15\end{array}$ & $\begin{array}{l}(2) \\
(3) \\
(2) \\
(1)\end{array}$ & $\begin{array}{l}1.00 \\
1.00 \\
1.00 \\
1.00\end{array}$ & $\begin{array}{l}(4) \\
(6) \\
(7) \\
(7)\end{array}$ & $\begin{array}{l}0.96 \\
0.97 \\
1.38 \\
3.77\end{array}$ & $\begin{array}{l}(9) \\
(6) \\
(6) \\
(5)\end{array}$ & $\begin{array}{l}3.76 \\
1.67 \\
2.70 \\
5.43\end{array}$ & $\begin{array}{l}(0) \\
(0) \\
(0) \\
(0)\end{array}$ & $\begin{array}{l}0 \\
0 \\
0 \\
0\end{array}$ \\
\hline
\end{tabular}

${ }^{*}$ Reference category. 
Table 12 SRRs for cancer, all sites combined (ICD 140-209), mortality according to duration of employment in various job categories

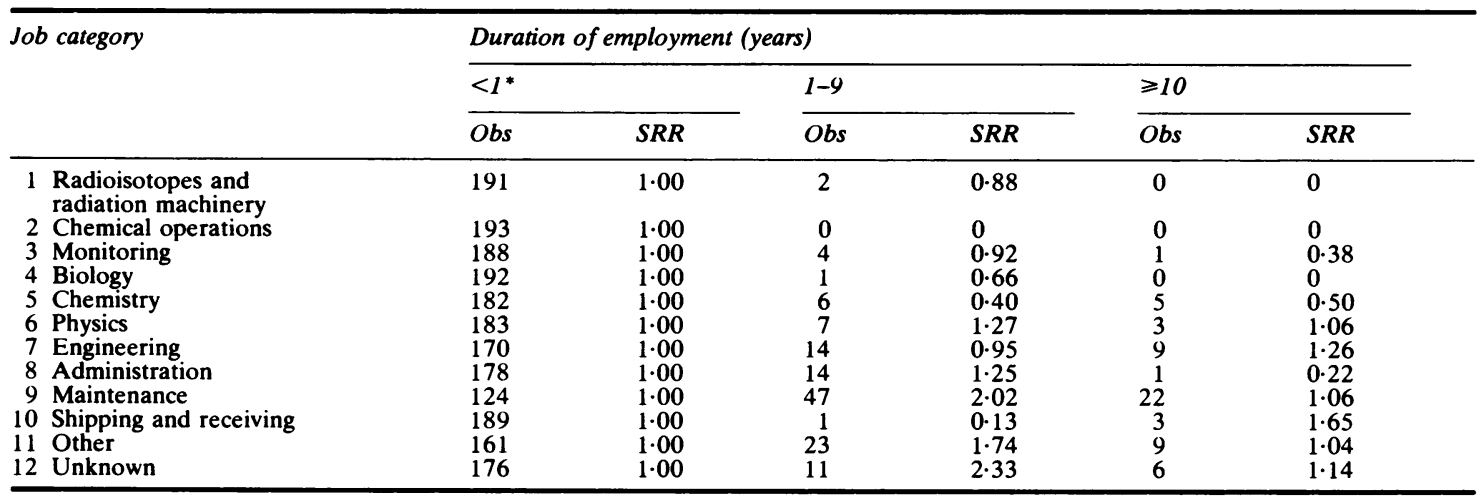

${ }^{*}$ Reference category includes people who never worked in a particular job category.

Table 13 SRRs for leukaemia (ICD 204-207) mortality according to duration of employment in various job categories

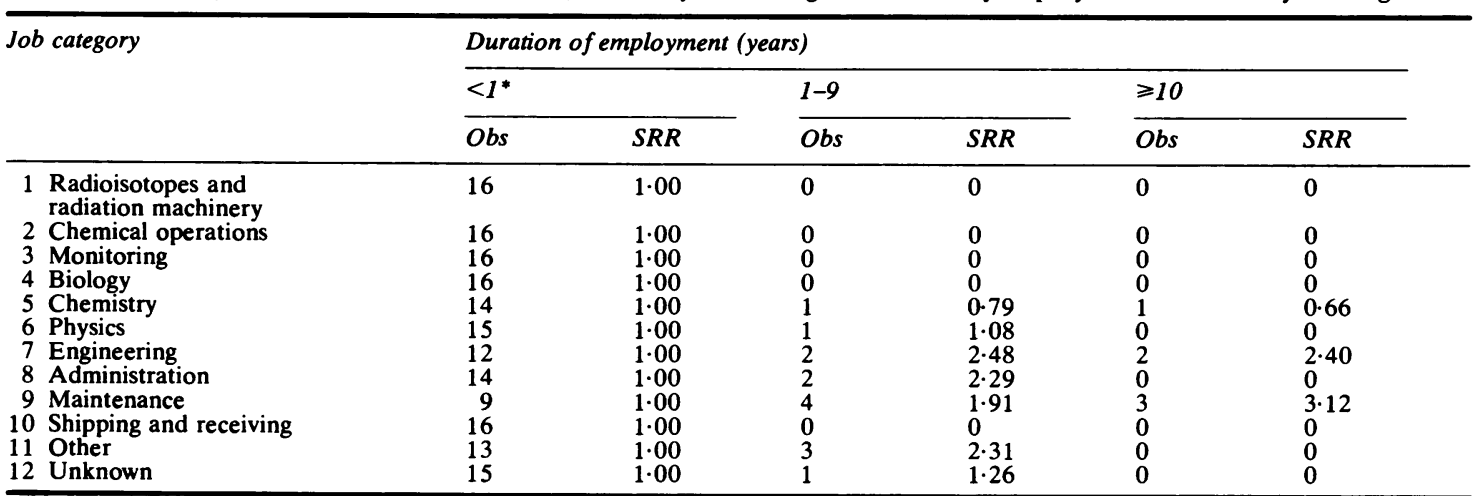

* Reference category includes people who never worked in a particular job category.

invoked as an explanation for reduced mortality risks in worker populations engaged in physically demanding activities, and may apply in the present context to welders, chemical operators, and some maintenance workers at ORNL. The ORNL workforce also includes a sizeable proportion, at most times $50 \%$ or more, of professional and technically trained individuals of high educational achievement. It is therefore likely that desirable lifestyle characteristics and health practices among such persons from the higher socioeconomic strata have been important contributors to their overall low mortality rate relative to the general population.

Mortality from leukaemia showed the most prominent excess, albeit only a modest rise (SMR $=1.49)$ that is not statistically significant. Slight excesses were observed for mortality from cancer of the prostate and from Hodgkin's disease. Whereas neither Hodgkin's disease nor prostatic cancer has been associated with radiation in previous studies, leukaemia has been reported often as a consequence of exposure to high doses of radiation. ${ }^{21}$ Examination of the dose effect trend for leukaemia mortality with external radiation did not show a regular increasing gradient because no deaths were observed in the highest ( $\geqslant 5$ rems) dose category. Further follow up of this population is needed to evaluate the stability of the dose effect relation. At present, the small number of person-years in the $\geqslant 5$ rems dose category precludes confident conclusions regarding mortality from leukaemia.

Some of the clinical and work exposure characteristics of the 16 deaths from leukaemia are listed in table 14. It is worth noting that, insofar as death certificates can be used as a reliable source of clinical information, four of the 16 cases were chronic lymphocytic leukaemia, which to date has not been associated with exposure to ionising radiation. ${ }^{22}$ 
Table 14 Characteristics of 16 deaths from leukaemia

\begin{tabular}{|c|c|c|c|c|c|c|c|}
\hline \multirow[t]{2}{*}{ Case } & \multirow{2}{*}{$\begin{array}{l}\text { Age at } \\
\text { death }\end{array}$} & \multirow{2}{*}{$\begin{array}{l}\text { Duration of } \\
\text { observation } \\
\text { (years)* }\end{array}$} & \multirow[t]{2}{*}{ Leukaemia type } & \multirow{2}{*}{$\begin{array}{l}\text { Total } \\
\text { employment } \\
\text { duration (years) }\end{array}$} & \multirow{2}{*}{$\begin{array}{l}\text { Cumulative } \\
\text { radiation } \\
\text { dose (rems) }\end{array}$} & \multicolumn{2}{|l|}{ Longest held job } \\
\hline & & & & & & $\overline{J o b}$ & $\begin{array}{l}\text { Duration } \\
\text { (years) }\end{array}$ \\
\hline $\begin{array}{r}1 \\
2 \\
3 \\
4 \\
5 \\
6 \\
7 \\
8 \\
9 \\
10 \\
11 \\
12 \\
13 \\
14 \\
15 \\
16\end{array}$ & $\begin{array}{l}52 \\
42 \\
61 \\
49 \\
62 \\
79 \\
73 \\
46 \\
57 \\
80 \\
51 \\
50 \\
54 \\
49 \\
50 \\
59\end{array}$ & $\begin{array}{r}20 \\
18 \\
17 \\
5 \\
22 \\
33 \\
29 \\
5 \\
20 \\
29 \\
24 \\
27 \\
11 \\
19 \\
18 \\
23\end{array}$ & $\begin{array}{l}\text { Acute leukaemia } \\
\text { Acute myeloid } \\
\text { Acute monocytic } \\
\text { Chronic lymphocytic } \\
\text { Chronic lymphocytic } \\
\text { Chronic lymphocytic } \\
\text { Chronic myeloid } \\
\text { Monocytic } \\
\text { Acute lymphocytic } \\
\text { Chronic lymphocytic } \\
\text { Leukaemia NOS } \\
\text { Leukaemia NOS } \\
\text { Leukaemia NOS } \\
\text { Acute myeloid } \\
\text { Monocytic } \\
\text { Acute leukaemia }\end{array}$ & $\begin{array}{r}20 \cdot 5 \\
18 \cdot 4 \\
17 \cdot 3 \\
5 \cdot 5 \\
6 \cdot 1 \\
4 \cdot 4 \\
3 \cdot 3 \\
0 \cdot 5 \\
20 \cdot 1 \\
14 \cdot 0 \\
24 \cdot 5 \\
4 \cdot 5 \\
0 \cdot 5 \\
18 \cdot 4 \\
0.7 \\
4 \cdot 4\end{array}$ & $\begin{array}{l}3 \cdot 360 \\
1 \cdot 125 \\
0 \cdot 685 \\
1 \cdot 160 \\
3 \cdot 570 \\
0.895 \\
0 \cdot 145 \\
\text { Unknown } \\
2 \cdot 005 \\
2 \cdot 870 \\
1.995 \\
1 \cdot 300 \\
0 \\
1 \cdot 135 \\
0 \\
0 \cdot 105\end{array}$ & $\begin{array}{l}\text { Welder } \\
\text { Instrument mechanic } \\
\text { Maintenance operator } \\
\text { Equipment operator } \\
\text { Electrician } \\
\text { Mechanic } \\
\text { Maintenance foreman } \\
\text { Machinist } \\
\text { Engineer } \\
\text { Engineer } \\
\text { Chemist } \\
\text { Chemistry technician } \\
\text { Chemist } \\
\text { Physicist } \\
\text { Technical trainee } \\
\text { Patrolman }\end{array}$ & $\begin{aligned} 18.6 \\
15.8 \\
13.7 \\
5.5 \\
2.6 \\
3.4 \\
2.2 \\
0.5 \\
20 \cdot 1 \\
7.2 \\
13.4 \\
3.7 \\
0 \cdot 3 \\
18.4 \\
0.7 \\
4 \cdot 2\end{aligned}$ \\
\hline
\end{tabular}

*Interval from first employment to death.

†As stated on death certificate.

NOS $=$ Not otherwise specified.

Also none of the 15 deaths for which data were available received cumulative radiation doses in excess of 5 rems, and, in fact, seven of these deaths had exposures of less than $1 \mathrm{rem}$. The doses of external radiation experienced occupationally by this cohort were low, even by comparison with typical background cosmic and terrestrial levels ${ }^{21}$; consequently, the absence of pronounced mortality excesses for leukaemia and other malignancies previously associated with exposure to radiation was not surprising.

The results from the analyses of mortality according to work experience in the various job categories indicate a possible association between the risk of leukaemia and a long duration of employment in engineering and maintenance jobs. The possible association with engineering has no obvious explanation, as radiation exposures experienced by engineers are variable, and chemical exposures are poorly characterised. Maintenance jobs involve a diversity of activities and potential exposures to radiation and to non-radioactive substances, including organic solvents, metals, and welding fumes. No particular job within the maintenance category shows a particular association with leukaemia (see table 14).

Further investigation of leukaemia among members of this cohort will focus on potential aetiological associations with specific chemical exposures encountered by workers in maintenance and other jobs. Additional follow up of the cohort should provide useful information concerning the dose effect relations of radiation with specific causes of death.

This work was performed as part of the Health and..
Mortality Study of United States Department of Energy workers being conducted by the Oak Ridge Associated Universities with the collaboration of the Department of Epidemiology, University of North Carolina at Chapel Hill. This research is supported under contract No DE-AC05-76OR000033 between the US Department of Energy, Office of Energy Research, and the Oak Ridge Associateo Universities.

Part of the data were collected under a previous contract from the Atomic Energy Commission, and later from the US Research and Development Administration (No E11-1-3438) under the direction of Dr T F Mancuso, University of Pittsburgh.

We are grateful to the staff of the Oak Ridge Associated Universities Death Certificate Retrieval Office for obtaining and processing mortality data, Dr K V Mani, Mr Bruce Parrish, and Mr Jack Beck for evaluating the radiation dosimetry data, Ms Martha Wray, Ms KeKe Gissel, Ms Shirley Siler, Ms Sharon Owens, and Mr Donald Robie for assembling the data base, Ms Sally Muller for computer programming help, and Ms Pamela Hooker and Ms Susan Kirstein for preparing this manuscript.

\section{References}

' Sevc J, Kunz E, Placek V. Lung cancer in uranium miners and long-term exposure to radon daughter products. Health Physics 1976;6:433-7.

2 deVilliers AJ, Windish JP. Lung cancer in a fluorspar mining community. I. Radiation, dust and mortality experience. $B r J$ Ind Med 1964;24:94-109.

${ }^{3}$ Axelson $\mathrm{O}$, Sundell L. Mining, lung cancer and smoking. Scand J Work Environ Health 1978;4:46-52. 
4 Rowland RE, Stehney AF, Lucas HF, Jr. Dose-response relationships for female radium dial workers. Radiat Res 1978; 76:368-83.

${ }^{5}$ Matanoski GM, Seltser R, Sartwell PE, Diamond EL, Elliott EA. The current mortality rates of radiologists and other physician specialists; specific causes of death. Am J Epidemiol 1975; 101:199-210.

- Najarian T, Colton T. Mortality from leukaemia and cancer in shipyard nuclear workers. Lancet 1978;i:1018-20.

${ }^{7}$ Rinsky RA, Zumwalde RD, Waxweiler RJ, et al. Cancer mortality at a naval nuclear shipyard. Lancet 1981;i:231-5.

${ }^{8}$ Mancuso TF, Stewart A, Kneale G. Radiation exposures of Hanford workers dying from cancer and other causes. Health Physics 1977;33:369-85.

9 Anderson TW. Radiation exposures of Hanford workers: a critique of the Mancuso, Stewart and Kneale report. Health Physics $1978 ; 35: 743-50$.

${ }^{10}$ Gofman JW. The question of causation in Hanford workers. Health Physics 1979; 79:122-48.

"Gilbert ES, Marks S. An analysis of the mortality of workers in a nuclear facility. Radiat Res 1979;79:122-48.

${ }^{12}$ Kneale GW, Mancuso TF, Stewart AM. Hanford radiation study III: a cohort study of the cancer risks from radiation to workers at Hanford (1944-77 deaths) by the method of regression models in life-tables. Br J Ind Med 1981;38:156-66.

${ }^{13}$ Government Accounting Office. Problems in assessing cancer risks of low-level ionizing radiation exposure. Vol 2. (Report to the Congress of the United States by the Comptroller General,
1981.) Washington, DC: United States Government Printing Office, 1981.

${ }^{14}$ Kneale GW, Mancuso TF, Stewart AM. Job related mortality risks of Hanford workers and their relation to cancer effects of measured doses of external radiation. $\mathrm{Br} J$ Ind Med 1984;41:9-14.

is Tolley HD, Marks S, Buchanan JA, Gilbert ES. A further update of the analysis of mortality of workers in a nuclear facility. Radiat Res 1983;95:211-3.

16 Monson RR. Analysis of relative survival and proportional mortality. Comput Biomed Res 1974;7:325-32.

17 Armitage P. Statistical methods in medical research. New York: Blackwell Scientific Publications, 1971.

${ }^{18}$ Miettinen OS. Standardization of risk ratios. Am J Epidemiol 1972;96:383-8.

${ }^{14}$ Cuzick J. Radiation-induced myelomatosis. N Engl J Med 1981;304:204-10.

${ }^{20}$ McMichael AJ. Standardized mortality ratios and the "healthy worker effect": scratching beneath the surface. J Occup Med 1976; 78: $165-8$.

${ }^{21}$ National Academy of Sciences, Committee on the Biological Effects of Ionizing Radiation. The effects on populations of exposure to low levels of ionizing radiation: 1980 . Washington, DC: National Academy Press, 1980.

22 United Nations Scientific Committee on the Effects of Atomic Radiation. Sources and effects of ionizing radiation. (Report to the General Assembly of the United States, publication No E77.1X.1, 1977.) New York: United Nations Press, 1977.

\section{Vancouver style}

All manuscripts submitted to the $\mathrm{Br} J$ Ind Med should conform to the uniform requirements for manuscripts submitted to biomedical journals (known as the Vancouver style).

The $\mathrm{Br} J$ Ind Med, together with many other international biomedical journals, has agreed to accept articles prepared in accordance with the Vancouver style. The style (described in full in $\mathrm{Br}$ Med J, 24 February 1979, p 532) is intended to standardise requirements for authors.

References should be numbered consecutively in the order in which they are first mentioned in the text by Arabic numerals above the line on each occasion the reference is cited (Manson' confirmed other reports ${ }^{2-5} \ldots$.). In future references to papers submitted to the $\mathrm{Br} J$ Ind Med should include: the names of all authors if there are six or less or, if there are more, the first three followed by $e t$ al; the title of journal articles or book chapters; the titles of journals abbreviated according to the style of Index Medicus; and the first and final page numbers of the article or chapter.

Examples of common forms of references are:

' International Steering Committee of Medical Editors. Uniform requirements for manuscripts submitted to biomedical journals. $\mathrm{Br}$ Med J 1979;1:532-5.

${ }^{2}$ Soter NA, Wasserman SI, Austen KF. Cold urticaria: release into the circulation of histamine and eosinophil chemotactic factor of anaphylaxis during cold challenge. $N$ Engl $J$ Med 1976;294:687-90.

' Weinstein L, Swartz MN. Pathogenic properties of invading micro-organisms. In: Sodeman WA Jr, Sodeman WA, eds. Pathologic physiology: mechanisms of disease. Philadelphia: W B Saunders, 1974:457-72. 